\title{
Amulab - Advanced multimedia learning laboratory
}

\author{
Cyril Brom
}

Amulab je laboratoř pokročilého multimediálního vzdělávání („,advanced multimedia learning laboratory“). Zkoumáme zde, jak se lidé učí z výukových materiálů, které kombinují verbální a obrazovou informaci; a zároveň takové materiály pomáháme vyvíjet. Praktický přesah je pro nás klíčový. Zaměřujeme se především na pokročilé materiály ve smyslu nových médií animace, výukové pořady, interaktivní simulace, výukové hry a podobně. $Z$ hlediska obsahu nás poslední dobou zajímá zejména výuka tzv. „,nové informatiky“ (podle revidovaných RVP), včetně prekoncepcí dětí o informatických tématech. Věnujeme se ale např́iklad i projektům, které směřují $\mathrm{k}$ dětem $\mathrm{s}$ poruchou autistického spektra nebo také psychologickým či vzdělávacím efektům videoher v neformálním vzdělávání. Za tímto účelem vyvíjíme vlastní hry a simulace na vážná témata, ale také softwarové nástroje pro sběr dat.

Sídlíme v budově Matematicko-fyzikální fakulty Univerzity Karlovy v Praze v Tróji. Spolupracujeme především s dětským kanálem České televize, herním studiem Charles Games, s laboratoří LABELS Psychologického ústavu Akademie věd ČR a s odborníky z Pedagogické a Filozofické fakulty Univerzity Karlovy. Naše projekty jsou financované zejména z programu Primus UK a prostřednictvím projektů Grantové agentury ČR.

Laboratoř vznikla na základě zájmu Cyrila Broma (Matematicko-fyzikální fakulta UK) a Víta Šislera (Filozofická fakulta UK) o problematiku výuky z multimediálních materiálů. Tomuto tématu se oba začali věnovat již v roce 2006 a vznik laboratoře je tak vyústěním jejich aktivit na tomto poli.

Webové stránky: https://ksvi.mff.cuni.cz/amulab/

Publikace: https://ksvi.mff.cuni.cz/amulab/index.php/publications/

Kontakt:amulab@ksvi.mff.cuni.cz

Brom, C. (2021). Amulab - Advanced multimedia learning laboratory. E-psychologie, 15(4), 91. https://doi.org/10.29364/epsy.425 